\title{
A DISSENT TO DR. WAELDER'S THEORY OF JUSTICE
}

\section{Clarence Morris $\dagger$}

Dr. Waelder (whose wisdom I have respected for years) sagely warns us against the ebullience of the marching songs of justice. However, his complacency about injustice foments my dissent.

David Hume, reacting in the eighteenth century to natural law theories of justice, said, "[T] he sense of justice and injustice is not derived from nature, but arises artificially . . . from education and human conventions." 1 Dr. Waelder concludes similarly, "All morality is a restriction and modification of inborn strivings. If man were good by nature no morality would be needed." 2 To this he adds a twentieth century psychiatric analysis built on the assumption that, since morality is not natural, the side of human nature to which the moralists wish to deny any place finds ways of seeping through the moral barriers. Mill made a similar nineteenth century case against sumptuary control in his On Liberty; he championed not only freedom of thought and free speech; he also tried to further "liberty of tastes and pursuits . . . without impediment from our fellow creatures, so long as what we do does not harm them, even though they should think our conduct foolish, perverse, or wrong." 3 Lack of freedom, said Mill, impedes the interests of man as a progressive being. Dr. Waelder asserts that repression will fail (at least in part) because pent up human nature fights back. Mill regrets that repression will succeed (at least in part) because it will muffle the joys of living.

Neither Hume nor Mill thought of suggesting that proper (though artificial) repressions should not or could not persist. Hume did not say that a glut of the artifice, justice, will be produced to man's prejudice. Mill did believe repression tended to go too far, but justice, for Mill, was society's insistent and needed prohibition of conduct injuring others, and, therefore, properly discouraged by disapproval or punishment.

$\dagger$ Professor of Law, University of Pennsylvania. LL.B. 1925, University of Colorado. LL.M. 1926, Columbia University. Member, Pennsylvania, Texas and Wyoming Bars.

12 Hume, A Treatise of Human Nature 189 (1956).

2 Waelder, The Concept of Justice and the Quest for a Perfectly Just Society, 115 U. PA. L. REv. 1 (1966) [hereinafter cited as Waelder].

3 Mill, Utilitarianism, Irberty, and Representative Govirnment 99 (1951). 
The wheel, too, is a nonnatural artifact. It seldom however, even though it is artificial, overdoes the artificiality of easy rolling; it is properly controlled by other artifacts called brakes, which in turn are suitably tested by using still other artifacts called testing machines. Use of the wheel tends to flatten it, and lay it up for repairs. A flat spot on the circumference of a wheel can impede an oxcart or a streamliner; such flatness, when it occurs, however, calls for counter-action, not complacency. The invention of the wheel followed on recognition of a clumsy aspect of the natural order-an inconvenience that could be meliorated by technology. Evil in the social order has likewise been recognized, and meliorated by morality and law prohibiting such outrages as slavery, child labor, droit du seigneur and imprisonment for debt. Repressions of these particular aggressive practices have not always worked; we occasionally hear of misdeeds violating these prohibitions. However, the prohibitions are not, I believe, only passing and partial victories for justice. Dr. Waelder says, "Who shall sacrifice what for the sake of whom is a question for which [he sees] . . no clear, unambiguous, moral answer." 4 Insofar as he means that no maxim, credo or rule book will solve all moral problems, he is, of course, correct. But powerful men can no longer claim a moral or legal right to slave labor, child labor, jus primae noctis or encagement of defaulting debtors. These, and many other specific advances in social justice, are widely accepted and seem quite robust. No one has successfully defined absolute justice, but men have generally agreed that certain specific injustices should be repressed.

Dr. Waelder counsels that demands for absolute justice be thought of as "conflicts of interest" so that "they can be adjusted with charity." " He says, "once we ideologize and moralize them and see them as conflicts between Good and Evil, they become inaccessible to compromise and thus insoluble, with nothing but violence left." 6 Surely we should not have proposed charitable compromise on genocide to Hitler. Either charity or compromise sometimes constitutes complicity. Of course the steps to be taken against injustice should be cooly planned, calmly executed and calculated not to be themselves unjust.

New justice of enduring value does not become a part of our morality and law in a trice. The charge that motor car manufacturers were not concerned enough with design safety was made years ago, but the accusation was, at first, hardly heard and it went long unheeded.

4 Waelder 8.

8 Ibid.

B Ibid. 
On the day on which I write these words, April 26, 1966, the newspapers say that the automobile manufacturers have capitulated to the demand for legal procedures that will advance safety in car design. No doubt the technical depths of this new justice will not be fathomed for a while, and concrete legal obligations will be developed slowly. Complacency has, however, evaporated and a new specific meliorative justice will take form and persist.

Dr. Waelder is right about the dangers of "ideologizing"-a wonderful word. The marching songs of justice may impede moral advance. Men who want to go about their useful lives can be shoved into the dilemma of having either to sing themselves into hoarse hysterical turmoil or to appear insensitive to injustice. The marching songs can stiffen resistance and sometimes generate a jangle so unsettling that concerted approval of proposed change becomes unthinkable. Until emerging new just values are widely and confidently shared, new just morals are not born and new just laws are not enacted. Sober restraint, however, differs from limp resignation. The Unconcerned, who do not affirmatively hold to the belief that mankind is an end in itself, and, therefore, that a man is properly used as a means only in the service of that end, smugly ignore indignities and cruelties which should be repressed.

Dr. Waelder, it seems to me, is more than negatively complacent; he affirmatively opposes attempts to remedy inequalities because, he believes, they can be corrected only by heavy-handed authoritarianism. He tells about studies of flocks of chickens and bands of baboons that lead to discovery of their social stratification, and then says:

After this cursory glance at phenomena of the animal kingdom we may return to our question: where does justice lie? Does it lie in sanctioning the order established in the free play of forces, as it is rooted in nature or in individual or collective history? Or does it lie in correcting and changing the natural order . . . . In any case, we must realize that if we feel that justice demands compensating for the inequalities of the natural order, authority is needed to carry out this compensation and to maintain it against the constant pressures of the natural order to reassert itself; and the further we wish to go in correcting the natural order, the more authoritarian the regime has to be. ${ }^{7}$

If by this passage Dr. Waelder means no more than that governmental intervention sometimes involves pernicious regimentation, he is, of course, correct. When an untried goodness is imposed upon society, the result may be more of an imposition than a good." But

7 Id. at 7. (Emphasis in last sentence added.) $\because \cdots$ 
can the status quo be changed only by strong-arming? Are effected changes invariably threatened by men who struggle to return to the status quo ante? Dr. Waelder looks askance when, in the name of justice, "equal treatment of all men [is advocated] regardless of how unequal they might be," 8 and especially so because "the ideal of equality of opportunity gradually turns into an ideal of equality of station." " The point he makes is that equality of station is an "unnatural" state in the societies of chickens, baboons and probably men; therefore, equality of station can endure only when an authoritarian warden constantly guards against innovations. Our experience does not bear Dr. Waelder out. In some ancient societies, for example, only a tycoon-father could afford to send daily letters by a private messenger to his distant son. Today our postal system has equalized (or almost so) that opportunity: letters are carried for a pittance to the sons of Lord Chesterfields and William Tells alike. The postal clerks who sell the stamps and sort the mails rarely draw distinctions between either father-senders or son-recipients. In this petty sphere we have equalized both opportunity and station. This insignificant example can be multiplied many times; we now enjoy many equalities of opportunity and station undreamed of a few generations ago. We do, of course, suffer from some regimentations also unknown to our forebears; advances, however, have not all resulted in noxious control.

Dr. Waelder discusses some hard problems. These illustrate to me that when two urgent and admirable interests clash in such a way that neither can be served except at the expense of the other, neither alternative can be properly called just or unjust. One of Dr. Waelder's examples is the dilemma of parents who can either send three normal children to college, or pay for special training for a retarded child, fitting him for uncaged life. Different people, says Dr. Waelder, will take different views as to which alternative is the more just. $^{10}$ In my opinion these agonized parents cannot act justly; they must find a less painful solution (or one must be afforded to them) or the justice of their decision should not be questioned. Either course will gnaw at their vitals; they should be praised if they can make either decision and not become so immobilized that they make no decision at all-to the prejudice of all four children. Outsiders who are unwilling to help, and who question the justice of either choice, are impertinent-to say the least.

Men's lives on earth have always been and will continue to be imperfect. Where man does not know how to be just, justice cannot 
prevail. An ingenious man may have a talent for perfecting new methods of torture and yet lack the ability to blaze new paths of justice. However, ingenuity that is prompted by compassion, and compassion which stimulates the search for practical advances in justices, will produce, in the long run, and bit by bit, a juster world.

We must agree with Dr. Waelder that prudish Victorian programs of sexual purity were overly strict and did not subdue the sexual aspect of man. Dr. Waelder says, as a qualified scientist, that "selfishness and aggressive self-assertion including . . . status differentiation" will also persist, regardless of attempts to wipe it out. ${ }^{11} \mathrm{I}$, of course, accept his professional statement. However, past history can be read as showing that both inequality in opportunity and inequality in station have been meliorated. Though there were times during which justice eroded and was lost, nevertheless the world has made advances in justice. The potentiality for more advances is not merely an ad hoc extrapolation, continuing the curve of experience onto an empty white chart. The pilot studies for some new meliorative justices have already been made and demonstrate the worth of pushing on.

Dr. Waelder is right in saying that absolute justice cannot be defined, much less realized. I do not challenge his view that aggressiveness in the form of status differentiation is rooted in human nature and therefore cannot be completely wiped out. Dr. Waelder has not said, however, that willingness to be the butt of such aggression is also inborn and therefore bound to persist. Honest and well-adjusted men should honor the talents of those more gifted than themselves, but they should not be asked, on this account, to think of themselves as less human or less representative of humanity. Dr. Waelder, whose whole thesis challenges the practicality of egalitarianism, says, "Justice . . . means for Aristotle to treat unequal things unequally. This concept can serve to justify practically everything. One can justify slavery in these terms and that is in fact what Aristotle has done." $12 \mathrm{We}$ have come a long way from Aristotle's justification of slavery as practiced in his own society. Perhaps a few ancient Greeks thought slavery unjust. It took two thousand years for opposition to slavery to gain momentum enough so that slavery was outlawed in the western world. No longer can we believe that a dull-witted man is condemned by nature to be a slave, and the injustice of slavery has been written (permanently, I think) into our laws. Shall we believe that since some are made so that we cannot down their aggressiveness in the form of status differentiation, others must inevitably be second class members of the human race? 